\title{
Analisis Tingkat Kesuburan Tanah Lahan Bekas Penambangan Batubara PT. Senamas Energindo Mineral Kabupaten Barito Timur Provinsi Kalimantan Tengah
}

\author{
Ermal Subhan ${ }^{1}$, Salampak $^{2}$, Andrie Elia Embang ${ }^{3}$, Masliani ${ }^{4}$ \\ ${ }^{1,}$ Mahasiswa Program Doktor Ilmu Lingkungan Universitas Palangka Raya \\ ${ }^{2,3,4}$ Program Studi Doktor Ilmu Lingkungan Universitas Palangka Raya \\ Surel: ${ }^{1}$ ermal_subhan@ pasca.upr.ac.id
}

\begin{abstract}
ABSTRAK
Kesuburan tanah adalah potensi tanah untuk menyediakan unsur hara dalam jumlah yang cukup dalam bentuk yang tersedia dan seimbang untuk menjamin pertumbuhan tanaman yang maksimum. Dalam rangka meminimalisasi kerusakan tanah bekas panambangan batubara dan proses degradasi lahan yang terus berlanjut, maka upaya konservasi tanah pada lahan bekas penambangan batubara perlu didukung oleh data informasi, diantaranya status tingkat kesuburan tanahnya. Penelitian ini bertujuan untuk mengetahui tingkat kesuburan tanah di lahan bekas penambangan batubara PT. Senamas Enegindo Mineral. Dari hasil penelitian ini didapatkan informasi tentang kondisi tanahnya yang diharapkan dapat dijadikan bahan pertimbangan dalam rangka upaya reklamasi dengan tujuan revegetasi di lahan bekas penambangan batubara. Metode yang digunakan untuk menentukan lokasi titik pengamatan ditentukan dengan cara purposive sampling. Sampel tanah terganggu diambil dari 5 titik pengamatan yang dilakukan dengan cara komposit kurang lebih sebanyak $1 \mathrm{~kg}$, selanjutnya dianalisis di laboratorium. Parameter yang diamati tekstur (pasir, debu, liat), C-organik, N, P, K-dd, Ca-dd, Na-dd, Mg-dd, kapasitas tukar kation (KTK), kejenuhan basa $(\mathrm{KB})$ dan $\mathrm{pH}\left(\mathrm{H}_{2} \mathrm{O}\right)$. Hasil penelitian menunjukkan tekstur tanah tergolong lempung berpasir dan pasir berlempung sedangkan tingkat kesuburan tanah pada lahan bekas penambangan batubara umumnya masih sangat rendah. Upaya perbaikan tingkat kesuburan tanah yaitu dengan pemberian pupuk organik dan anorganik, kompos dan jamur mikoriza.
\end{abstract}

Kata kunci

\section{PENDAHULUAN}

Kesuburan tanah dievaluasi dengan analisis tanah dan tanaman baik total maupun parsial, yang ditujukan untuk menentukan manajemen yang diperlukan untuk rekomendasi pemupukan dan meningkatkan kesuburan suatu $\operatorname{tanah}^{[1]}$.
Penilaian status kesuburan tanah biasanya didasarkan kandungan Nitrogen, Fosfor, dan Kalium, karena unsur hara makro ini dibutuhkan dalam jumlah banyak ${ }^{[2]}$. Selanjutnya ketersediaan suatu unsur hara dipengaruhi oleh faktor tanah seperti: 
tekstur, kapasitas tukar kation, kandungan bahan organik, dan $\mathrm{pH}$ tanah $^{[1]}$.

Kegiatan penambangan yang dilakukan oleh pemegang Izin Usaha Pertambangan PT. Senamas Energindo Mineral menggunakan sistem tambang terbuka (Open Pit), kegiatan pertambangan meliputi: pekerjaan pembersihan lahan (Land Clearing), pengupasan tanah penutup (Overburden), pembongkaran lapisan batubara dan pengangkutan batubara baik ke stok pile lapangan maupun pelabuhan untuk dilakukan penjualan batubara kepada pembeli.

Kegiatan Penambangan Batubara yang dilakukan oleh PT. Senamas Energindo Mineral tidak sesuai dengan kaidah pengelolaan pertambangan yang baik dan benar (good mining practice) sehingga pasca penambangan lahan bekas tambang batubara dampak kegiatan adanya perubahan topografi lahan berupa void atau lubang bukaan bekas galian baik terisi air maupun tidak, timbunan overburden, penurunan sifat fisik dan kimia tanah.

Lahan pertambangan bekas penambangan perlu segera direklamasi dan direvegetasi untuk mengembalikan ekositem dan iklim mikro, kesuburan tanah serta fungsi peyimpan air. Karakteristik reklamasi adalah tempat terbuka, intensitas sinar tinggi, temperatur tinggi dan berfluktuasi ekstrem, $\mathrm{pH}$ rendah dan degradasi jumlah spesies baik flora, fauna maupun mikroorganisme tanah. Karakteristik yang demikian menyebabkan tidak semua jenis tumbuhan dapat hidup pada lahan tersebut ${ }^{[3]}$.

Menurut Cooke \& Johnson ${ }^{[4]}$ menunjukan bahwa lahan pasca tambang batubara secara umum dicirikan oleh tekstur fisik yang sangat kasar dan beragam, mulai lempung sampai lempung berpasir. Pada beberapa lokasi penambangan nampak berbatu, dan pada tektur yang sangat halus tidak memiliki kandungan bahan organik, sangat kompak, dan laju infiltrasi airnya sangat rendah. Pada umumnya lahan bekas penambangan memiliki kandungan hara makro yang sangat rendah, terutama kandungan $\mathrm{N}, \mathrm{P}, \mathrm{K}, \mathrm{Na}$ dan $\mathrm{Ca}$, serta tingkat kemasaman tanah pH dan Kapasitas Tukar Kation (KTK) yang rendah. Selain itu mikroorganisme tanah yang sangat membantu dalam stabilisasi struktur tanah, sumbangan mineral-mineral inorganik, ataupun sumbanganya dalam zat pengatur pertumbuhan, juga sangat rendah ${ }^{[5]}$.

Dalam rangka meminimalisasi kerusakan tanah bekas panambangan batubara dan proses degredasi lahan yang terus berlanjut, maka upaya konservasi tanah pada lahan bekas penambangan batubara perlu didukung oleh data informasi, diantaranya status tingkat kesuburan tanahnya. Penelitian ini bertujuan untuk mengetahui tingkat kesuburan tanah di lahan bekas penambangan batubara. Dari hasil penelitian ini didapatkan informasi tentang kondisi tanahnya yang diharapkan dapat dijadikan bahan pertimbangan dalam rangka upaya reklamasi dengan tujuan revegetasi pada lahan bekas penambangan batubara.

\section{METODE PENELITIAN}

\section{Lokasi dan Alat Digunakan}

Lokasi Izin Usaha Pertambangan PT. Senamas Energindo Mineral secara administrasi terletak pada Kecamatan dusun timur, Karusen janang, dan Awang Kabupaten Barito Timur Provinsi Kalimantan Tengah dengan luas wilayah \pm 2.000 ha. Pencapaian lokasi dari Jakarta dicapai dengan menggunakan transportasi udara menuju kota Palangka Raya atau kota Banjarmasin dari bandara Syamsudin Noor Banjarmasin menuju Tamiang Layang dapat ditempuh dengan menggunakan transportasi udara via bandara perintis Warukin di Tanjung wilayah Banjarmasin dengan waktu tempuh \pm 30 menit, dari bandara perintis Warukin di Tanjung menuju tamiang Layang dengan waktu tempuh \pm 1 jam 30 menit. Alternatif lain apabila pesawat perintis tidak beroperasi, dari Banjarmasin menuju Tamiang Layang data ditempuh melalui jalan darat dengan waktu tempuh selama \pm 6 jam. Lokasi kesampaian daerah dapat dilihat dalam Gambar 1. 


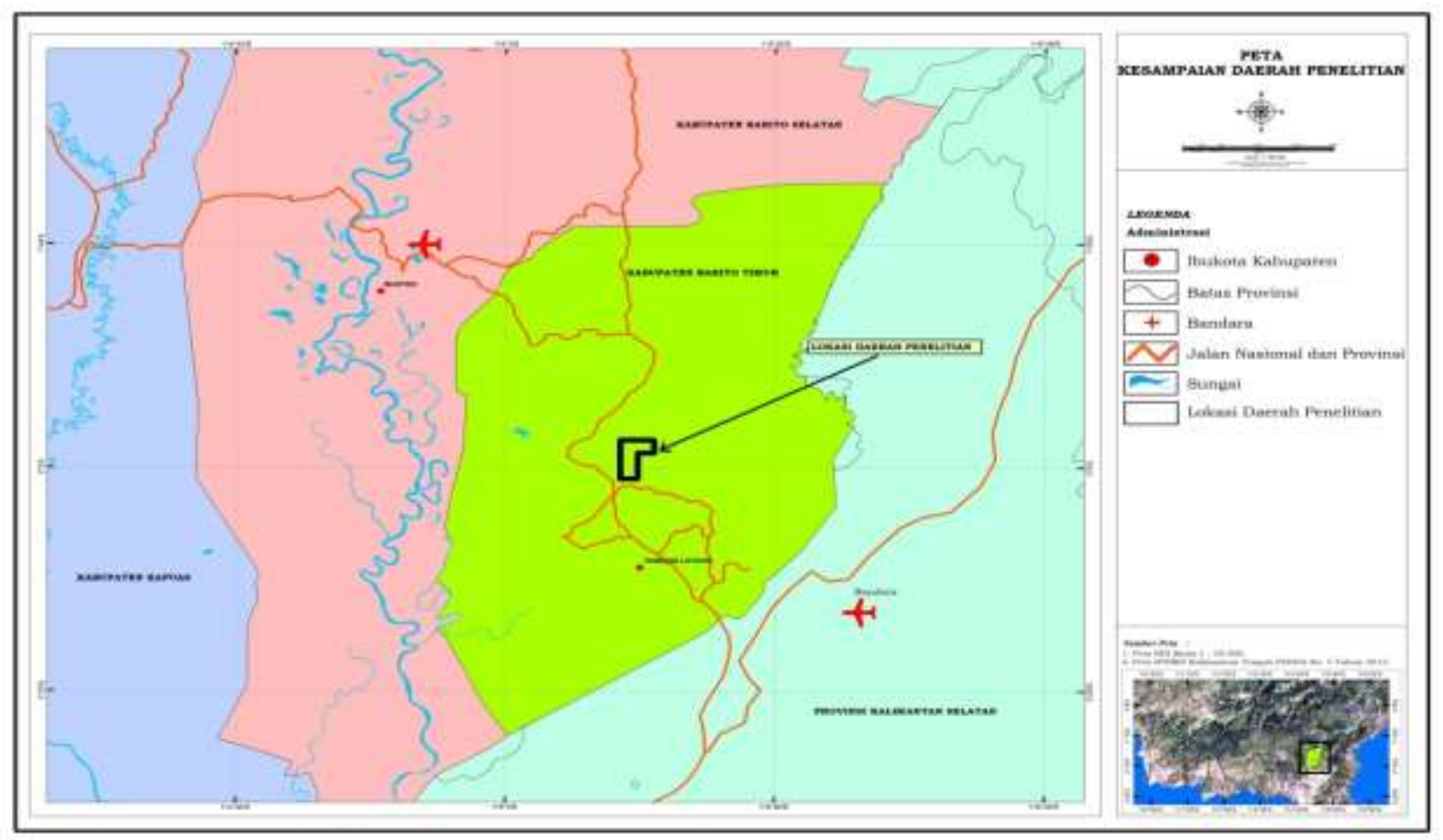

Gambar 1. Lokasi kesampaian daerah penelitian

Alat yang diperlukan antara lain adalah kompas; ring sample tanah; cangkul; GPS, parang; pisau; kantong contoh ; meteran; dan alat tulis menulis. Sedangkan obyek penelitian adalah tanah dari lahan bekas penambangan batubara belum reklamasi dan timbunan tanah. Peta lokasi pengambilan sampel dapat dilihat pada Gambar 2.

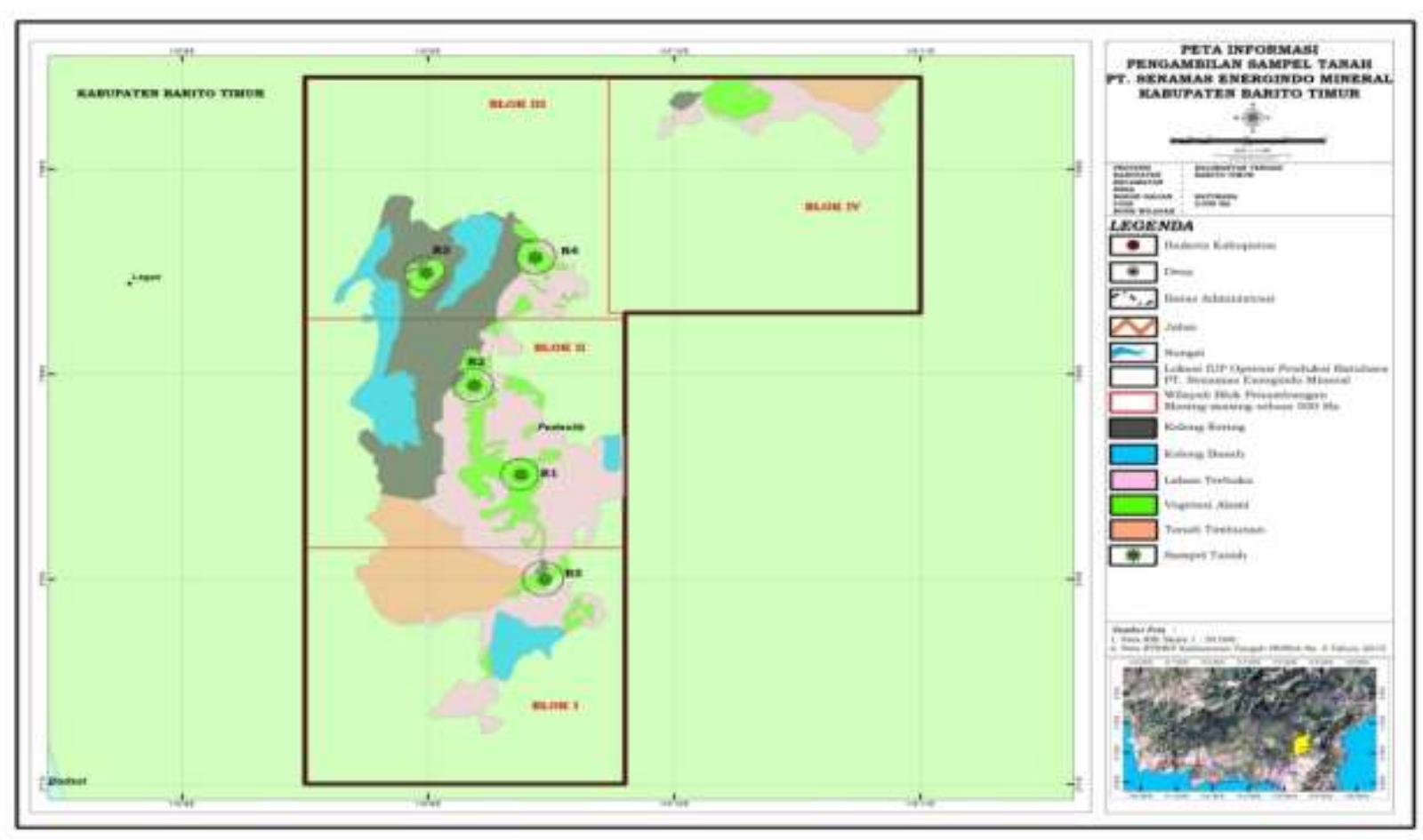

Gambar 2. Peta Lokasi Pengambilan Sampel Tanah 


\section{Metode Penelitian}

Untuk mendapat sifat fisik dan kimia tanah dilakukan dengan cara sebagai berikut:

a) Menentukan titik pengambilan sampel tanah dilakukan dengan cara purposive sampling sebanyak 5 titik pengamatan;

b) Pada titik pengamatan diambil sampelnya pada lapisan lahan pada kedalaman antara $0-20 \mathrm{~cm}$ dengan menggunakan dengan cara komposit, yakni contoh tanah diambil dengan jarak masing-masing +1 meter searah mata angin, kemudian dicampur serta diaduk secara merata (dikompositkan), kemudian diambil sebanyak kurang lebih $1 \mathrm{~kg}$;

c) Sebanyak 5 sampel tanah yang telah diambil kemudian di analisis di laboratorium untuk diketahui keadaan sifat fisik dan kimia tanahnya.

\section{Analisis Data}

Data hasil analisis laboraterium terhadap sifat fisik, selanjunya akan dibandingkan dengan kriteria penilaian kelas tekstur tanah Sistem USDA (United States Department of Agriculture), dan data hasil analisis laboratorium terhadap sifat kimia tanah selanjutnya akan dibandingkan dengan kriteria penilaian kesuburannya menurut Lembaga Pusat Penelitian Tanah (LPPT), Bogor tahun1983.

\section{HASIL DAN PEMBAHASAN Analisis Sifat Fisik Tanah}

Dari hasil analisa secara teknis di laboratorium dan pengamatan secara kualitatif di lapangan diperoleh data sifat fisik dilahan bekas penambangan batubara.
Hasil analisis laboratorium unsur pasir terendah pada lokasi R5 1,45\% dan tertinggi pada lokasi R4 14,71\%. Unsur debu terendah pada lokasi R4 26,05\% dan tertinggi pada lokasi R1 42,7\%. Unsur liat terendah pada lokasi R1 0,55\% dan tertinggi pada lokasi R2 $0,64 \%$.

Berdasar hasil perbandingan dengan kelas tekstur tanah sistem USDA (United States Department of Agriculture), dapat dilihat dalam Tabel 1. Pada lokasi pengamatan tekstur tanah tergolong klasifikasi lempung berpasir sampai pasir berlempung, yang termasuk tekstur lempung berpasir terdapat pada lokasi R1, R2, R3, dan $\mathrm{R} 5$, sedangkan R4 bertekstur pasir berlempung.

Menunjukkan bahwa tekstur tanah dilahan bekas penambangan batubara klasifikasi lempung berpasir (lempung halus sampai pasir halus), menunjukkan bahwa fraksi lempung lebih dominan pada fraksi tanah lainnya. Tanah jenis ini dapat dikategorikan tanah yang dapat menahan air dan unsur hara. Sedangkan tekstur tanah di lahan bekas penambangan batubara klasifikasi pasir berlempung (pasir agak kasar sampai lempung halus), menunjukkan bahwa fraksi pasir lebih dominan pada fraksi tanah lainnya. Tanah jenis ini dapat dikategorikan tanah yang tidak dapat menahan air dan miskin unsur hara. Pada lokasi R4 klasifikasi tekstur pasir berlempung menunjukan tingkat kemiringan lahan lebih curam dengan ditunjukkan dengan tingkat pencucian hasil erosi lebih tinggi di banding lokasi R1, R2, R3 dan R5 klasifikasi tekstur lempung berpasir kemiringan lahan lebih landai.

Tabel 1 Sifat Fisik Tanah di Lahan Bekas Penambangan Batubara

\begin{tabular}{lcccccc}
\hline \multirow{2}{*}{ Parameter } & \multirow{2}{*}{ Satuan } & \multicolumn{5}{c}{ Lokasi Pengamatan } \\
\cline { 2 - 7 } & & Lokasi R-1 & Lokasi R-2 & Lokasi R-3 & Lokasi R-4 & Lokasi R-5 \\
\hline \multirow{2}{*}{ Tekstur } & - & $\begin{array}{c}\text { Lempung } \\
\text { berpasir }\end{array}$ & $\begin{array}{c}\text { Lempung } \\
\text { berpasir }\end{array}$ & $\begin{array}{c}\text { Lempung } \\
\text { berpasir }\end{array}$ & $\begin{array}{c}\text { Lempung } \\
\text { berpasir }\end{array}$ & $\begin{array}{c}\text { Lempung } \\
\text { berpasir }\end{array}$ \\
\hline - Pasir & $\%$ & 1,99 & 1,74 & 1,83 & 14,71 & 1,45 \\
- Debu & $\%$ & 42,7 & 34,36 & 36,29 & 26,05 & 39,92 \\
- Liat & $\%$ & 0,55 & 0,64 & 0,62 & 0,59 & 0,59 \\
\hline
\end{tabular}

Sumber: Hasil Uji Sifat Fisik Tanah pada Laboratorium Universitas Palangka Raya 


\section{Analisis Sifat Kimia Tanah}

Hasil analisis sifat kimia tanah pada lokasi R1 sampai R5 memperlihatkan unsur C organik terendah pada lokasi R2 sebesar 0,16\% tertinggi pada lokasi R1 sebesar $0,24 \%$. Unsur $\mathrm{N}$ terendah pada lokasi $\mathrm{R} 2$ sebesar $0,45 \%$ dan tertinggi pada lokasi R3 sebesar $1,55 \%$. Unsur P terendah pada lokasi R4 sebesar 22,22 ppm tertinggi pada lokasi R5 sebesar 43,31 ppm. K-dd terendah pada lokasi R4 0,01 me/100gr tertinggi pada lokasi R3 sebesar 0,36 me/100gr. Ca-dd terendah pada lokasi R4 0,77 me/100gr tertinggi pada lokasi R3 sebesar 8,49 me/100gr. Mg-dd terendah pada lokasi R1 0,82 me/100gr tertinggi pada lokasi R3 sebesar 1,64 me/100gr. Na-dd terendah pada lokasi R2, R4 dan R5 0,03 me/100gr tertinggi pada lokasi R3 sebesar 0,16 me/100gr. KB terendah pada lokasi R4 4,64\% tertinggi pada lokasi R3 sebesar 25,13\%. KTK terendah pada lokasi R5 20,23 me/100gr tertinggi pada lokasi R3 sebesar 42,39 me/100gr dan $\mathrm{pH} \quad\left(\mathrm{H}_{2} \mathrm{O}\right)$ terendah pada lokasi R2 5,12 tertinggi pada lokasi R5 sebesar 5,28. Klasifikasi tingkat kesuburan tanah dapat dilihat pada Tabel 2.

\section{Tingkat Kesuburan Tanah}

Tingkat kesuburan tanah pada lokasi R1 sampai R5 unsur C-organik semua lokasi penelitian tergolong sangat rendah. Unsur $\mathrm{N}$ di lokasi R2, R4 dan R5 tergolong sedang. Lokasi R1 dan R3 tergolong sangat rendah, unsur P lokasi R1 dan R4 tergolong sedang, lokasi R2, R3 dan R5 tergolong tinggi. Unsur K-dd semua lokasi penelitian tergolong sangat rendah. Unsur Ca-dd lokasi R3 tergolong sedang, R1, R2, R4 dan R5 tergolong sangat rendah. Unsur Mg-dd lokasi R1, R2, tergolong rendah, R3 tergolong sedang, lokasi R4 dan R5 tergolong sangat rendah. Unsur Na-dd semua lokasi penelitian tergolong sangat rendah. Unsur KB lokasi R3 tergolong rendah, lokasi R1, R2, R4 dan R5 tergolong sangat rendah. KTK lokasi R3 dan R5 tergolong sedang, R1 dan R2 tergolong tinggi dan lokasi $\mathrm{R} 3$ tergolong sangat tinggi, dan $\mathrm{pH}$ $\left(\mathrm{H}_{2} \mathrm{O}\right)$ semua lokasi penelitian tergolong agak masam. Dapat disimpulkan bahwa tingkat kesuburan tanah dilahan bekas penambangan batubara tergolong dominan sangat rendah. Lihat pada Tabel 2.

Tabel 2 Sifat Kimia Tanah di Lahan Bekas Penambangan Batubara

\begin{tabular}{|c|c|c|c|c|c|c|}
\hline \multirow{2}{*}{ Parameter } & \multirow{2}{*}{ Satuan } & \multicolumn{5}{|c|}{ Lokasi Pengamatan } \\
\hline & & Lokasi R.1 & Lokasi R.1 & Lokasi R.1 & Lokasi R.1 & Lokasi R.1 \\
\hline $\mathrm{C}$ & $\%$ & $0,24(\mathrm{SR})$ & $0,16(\mathrm{SR})$ & $0,2(\mathrm{SR})$ & $0,21(\mathrm{SR})$ & $0,18(\mathrm{SR})$ \\
\hline $\mathrm{N}$ & $\%$ & 1,18 (SR) & $0,45(\mathrm{R})$ & 1,55 (SR) & $0,5(\mathrm{~S})$ & $0,46(\mathrm{~S})$ \\
\hline $\mathrm{P}$ & $\mathrm{ppm}$ & $23,74(\mathrm{~S})$ & $34,98(\mathrm{~T})$ & $31,28(\mathrm{~T})$ & $22,22(\mathrm{~S})$ & 43,31 (T) \\
\hline K-dd & $\mathrm{me} / 100 \mathrm{gr}$ & 0,23 (SR) & 0,05 (SR) & 0,36 (SR) & 0,01 (SR) & 0,04 (SR) \\
\hline Ca-dd & $\mathrm{me} / 100 \mathrm{gr}$ & $1,51(\mathrm{SR})$ & 1,38 (SR) & $8,49(\mathrm{~S})$ & 0,77 (SR) & 0,84 (SR) \\
\hline Mg-dd & $\mathrm{me} / 100 \mathrm{gr}$ & $0,82(\mathrm{R})$ & $0,99(\mathrm{R})$ & $1,64(\mathrm{~S})$ & $0,2(\mathrm{SR})$ & 0,26 (SR) \\
\hline Na-dd & $\mathrm{me} / 100 \mathrm{gr}$ & 0,06 (SR) & 0,03 (SR) & 0,16 (SR) & 0,03 (SR) & 0,03 (SR) \\
\hline KB & $\%$ & 8,92 (SR) & 9,67 (SR) & $25,13(\mathrm{R})$ & 4,64 (SR) & 5,78 (SR) \\
\hline KTK & $\mathrm{me} / 100 \mathrm{gr}$ & $29,37(\mathrm{~T})$ & 25,29 (T) & $42,39(\mathrm{ST})$ & $21,83(\mathrm{~S})$ & $20,23(\mathrm{~S})$ \\
\hline $\mathrm{pH}\left(\mathrm{H}_{2} \mathrm{O}\right)$ & - & $5,13(\mathrm{AM})$ & $5,12(\mathrm{AM})$ & $5,24(\mathrm{AM})$ & $5,2(\mathrm{AM})$ & $5,28(\mathrm{AM})$ \\
\hline
\end{tabular}

Sumber: Hasil Uji Kimia Tanah pada Laboratorium Universitas Palangka Raya

Perubahan sifat fisik dan kimia tanah pada lahan bekas penambangan batubara PT. Senamas Energindo Mineral disebabkan pada saat kegiatan pengupasan tanah penutup (top soil) terutama tanah unsur hara tidak dilakukan pengelolaan dengan baik sehingga tanah yang subur tercampur dengan tanah overburden yang tidak subur dan tanah yang subur ditimpa oleh tanah yang tidak subur. Karena tanah tidak terkelola dengan baik seiring dengan berjalan waktu dengan kondisi lahan tidak tertata dengan baik maka unsur hara seperti C-organik, $\mathrm{N}, \mathrm{P}, \mathrm{K}, \mathrm{Mg}, \mathrm{Ca}, \mathrm{Mn}$, $\mathrm{KB}$ pada saat musim hujan larut atau tercuci mengakibatkan berkurang atau hilangnya unsur hara pada lahan bekas penambangan batubara.

Menurut Margaretha ${ }^{[6]}$, kegiatan penambangan menyebabkan perubahan fisik dan kimia tanah, sehingga menurunkan 
kualitas dari tanah tersebut. Pada umumnya tanah galian batubara ditumpuk diatas tanah yang produktif, dengan susunan yang terbalik dari susunan awalnya, tanah lapisan atas (top soil). Dalam beberapa tahun pertama areal bekas penambangan batubara sulit untuk ditumbuhi vegetasi. Hal ini disebabkan oleh beberapa faktor yaitu tanah yang terlalu padat, struktur tanah tidak mantanp, aerasi dan drainase buruk serta tanah lambat meresap air. Terdapat pula kendala kimia seperti $\mathrm{pH}$ yang sangat masam dan rendahnya tingkat kesuburan tanahnya. Fenomena ini sejalan dengan Hardjowigeno ${ }^{[7]}$ perubahan sifat fisik kimia tanah yang terjadi seperti perubahan tektur, konsistensi struktur, batas antar lapisan tanah, sedangkan perubahan sifat kimia tanah misalnya perubahan kandungan hara dalam tanah, C-organik, $\mathrm{pH}$ tanah, keadaan yang seperti ini menyebabkan tanah-tanah bekas penambangan menjadi sulit untuk ditumbuhi berbagai tumbuhan termasuk untuk kegiatan pertanian dikarenakan pertumbuhan tanaman terhambat dan produktivitas tanah menurun [8].

\section{Upaya Memperbaiki Tingkat Kesuburan Tanah}

Hasil analisis tingkat kesuburan tanah dilahan bekas penambangan tergolong sangat rendah upaya yang dilakukan untuk perbaikan sifat fisik dan kimia tanah dapat dilakukan yaitu:

1. Untuk meningkatkan dan menunjang pertumbuhan batang, daun, akar, buah dan biji berikan pupuk N, P, K.

2. Pemberian pupuk organik yang berasal dari tanaman dan hewan misalnya emulsi atau hidrolisat ikan bisa jadi pupuk yang sangat baik untuk pertumbuhan mikroba dalam jangka panjang, sehingga tanah akan tetap kaya dengan nutrisi serta gembur.

3. Gunakan pupuk kandang atau bahan lainnya contoh kotoran ayam, kambing, sapi dll. Tambahkan tepung tulang untuk menambah kandungan fosfor atau tepung darah kering untuk menambah kandungan nitrogen.

4. Berikan kompos untuk memperbaiki tekstur dan nutrisi tanah.
5. Tambahkan jamur atau bakteri yang bermanfaat contoh jamur yang berfanfaat jamur mikoriza jamur ini akan melekat pada akar tanaman akan membantu tanaman menyerap lebih banyak air dan nutrisi.

\section{KESIMPULAN}

1. Analisis tekstur tanah di lahan bekas penambangan batubara klasifikasi lempung berpasir bahwa fraksi lempung lebih dominan daripada fraksi tanah lainnya, dan klasifikasi pasir berlempung bahwa fraksi pasir lebih dominan pada fraksi tanah lainnya.

2. Analisis tingkat kesuburan tanah dilahan bekas penambangan batubara tergolong dominan sangat rendah

3. Upaya perbaikan tingkat kesuburan tanah yaitu dengan pemberian pupuk organik dan anorganik, kompos dan jamur mikoriza.

\section{SARAN}

Kegiatan penataan, pengaturan lahan segera dilakukan dengan kaidah konservasi tanah dan air, agar tingkat kesuburan tanah tetap terjaga, dan dilakukan penanaman vegetasi yang sesuai dengan kondisi lahan bekas penambangan batubara.

\section{DAFTAR PUSTAKA}

[1] FAO, 1988, Soil and Plant Analysis, FAO Soil Bulletin, 38/1, Roma, 241p.

[2] Gillman, G P., 1983, Nutrient Availability in Acid Soils of the Tropics Following Clearing and Cultivivation Proceedings of the International Workshop on Soil. Research resolve selected problems of soil in tehe tropics Townville Queensland Australia 12-16 September.

[3] Rahmawaty, 2002, Restorasi Lahan Bekas Tambang Berdasarkan Kaidah Ekologi, Fakultas Pertanian, Universitas Sumatera Utara, Medan.

[4] Cooke, J. A., Johnson, M. S., 2002, Ecological Restoration of Land with Particular reference To The Mining of Metals and Industrial Minerals: A Review Of Theory and Practice, Environmental Review, 10, 41-71. 
[5] Adman B., 2012, Potensi Jenis Pohon Lokal Cepat Tumbuh untuk Pemulihan Lingkungan Lahan Pascatambang Batubara (Studi Kasus di PT. Singlurus Pratama, Kalimantan Timur). Tesis, Program Pascasarjana Universitas Diponegoro, Semarang.

[6] Margaretha, 2010, Pemanfatan Tanah Bekas Tambang Batubara Dengan Pupuk Hayati Mikoriza Sebagai Media Tanam Jagung Manis, 1 (3), 1-10.

[7] Hardjowigeno, S., 2003, Klasifikasi Tanah dan Pedogenesis, Jakarta, Akademika Pressindo.

[8] Pribadi A., 2012, Reklamasi Lahan Bekas Tambanag Batubara, Fakultas Pertanian, Universitas Pembangunan Nasional Veteran, Yogyakarta. 